\title{
Politics in Decentralization': The Appointment of Metropolitan, Municipal and District Chief Executives (MMDCEs) in Ghana
}

\author{
Abdul-Wadudu Adam Mohammed
}

\begin{abstract}
Volumes of studies have examined Ghana's decentralization. But none has looked at the politics in the appointment of metropolitan, municipal and district chief executives (MMDCEs) - the political heads of the districts in Ghana, which is not only political but partisan and perennially contentious. The objective of this paper is to fill the gap by identifying the political actors in the process of appointing MMDCEs, their interests, the tension and the elements of the political furore among them. Making MMDCEs elective in Ghana is also examined.
\end{abstract}

Keywords: Politics, Decentralization, District Chief Executive, Ghana

\section{INTRODUCTION}

"For too long, decentralization has been considered a technical issue. ... Decentralization is a political act. It is driven by political considerations, and its outcome will depend on how the political forces that stand to gain stack up against those that may lose. ... this perspective help explain the experience with decentralization in many countries ..." - Shanta Devarajan, Chief Economist of the Africa Region at the World Bank (Quoted in Eaton et al., 2010)

Since 1980, the single most transformative happenings in the sphere of the state and governance in Africa is decentralization - the center ceding some authority to the periphery. This change has not gone entirely unnoticed by practitioners, analysts and researchers both within and outside Africa. In the past decades, several dimensions of decentralization are examined including the types and forms (Treisman, 2000); the impact of decentralization on the quality of government (Treisman, 2000, Faguet, 2011); designing an effective decentralized system (Kauzya, 2007) and the effects of decentralization on aid effectiveness (Easton, et al., 2010), interpretations of decentralization (UNDP, 1999), just to mention few works thus far. ${ }^{2}$

The literature on decentralization largely center on the technical dimensions of decentralization. Meanwhile, "No matter what the official justification," Eaton et al (2010: 1) stress, "decentralization is largely driven and continually shaped by politics and institutional dynamics". Ndegwa and Levy (2003: 3) noted "The technical literature, however, tends to neglect the political underpinnings of decentralization". "Politicians and bureaucrats fight over decentralization for the same reason that they fight over the design of state institutions more generally: their power and authority are at stake" (Eaton et al., 2010). While decentralization remain political through sub-national elections (Eaton et al., 2010), partisanship is fast gaining

\footnotetext{
${ }^{1}$ I distinguish politics of decentralization from politics in decentralization. Political of decentralization is the politics involved in the design and decentralization of authority from state to local level. Politics in decentralization is essentially the politics involved in the management and administration of decentralized systems.

2 See Ayee (2008) for detailed categorization of the literature on decentralization
} 
grounds in the decentralization arena not only over the design, but how decentralization is ran. Partisanship has crept into both sub-national elections and aspects of local governance that are based on appointments. Scholars have shown politics' critical role in the creation of districts basic units of local governance - in Ghana (Ayee, 2008; Mohammed, 2015). The resourcing of the metropolitan, municipal and district assemblies (MMDAs) is equally found to be imbued with more politics than is legally allowed (Ankamah, 2012). The partisan nature of decentralization (the local assemblies in particular) in Ghana is also examined in Adamtey (2014). But the politics and partisanship that surrounds the appointment of metropolitan, municipal and district chief executives (MMDCEs) in Ghana has remained a grey area.

Political parties are governments in waiting seeking opportunity to govern through competitive elections. The moment a party wins an election in Ghana, another level of competition ensues - internal struggle and competition within parties for appointments including MMDCE roles in the yet to be constituted government. While political parties perform organizational functions by coalescing interests groups (Fukuyama, 2014), such integration of interests involves more binding party interests such as the quest to win power. However, interests of diverse individual and smaller groups within bigger party interests remain difficult for political parties to harmonize. The time such interests have proven formidable to manage is during the nomination and confirmation into office the chief executives of the various districts of Ghana when a party comes to party and charged with the Constitutional duty to form a government including appointing MMDCEs into the 216 metropolitan, municipal and district assemblies of Ghana. But the process of appointing/nominating MMDCEs is not clean and smooth: the various interests groups make the formation of new government at the local level tumultuous when a party is forming government after winning elections. Common interest groups include grassroots supporters, party executives, party elders at various level of parties' structure and traditional and opinion leaders in the Ghanaian society.

When the campaign and elections curtains are drawn, appointment of MMDCEs are sites for naked, partisan politics manifesting in various ways, fueled by perceived legitimacy issues of appointees. Often, importance is attached to executives who constitutionally represent the President at the local level. At the local level, MMDCEs administer the execution of the mandate of the President and his government through the implementation of the various policies and programmes envisioned. They also serve as the link between central government and the local people as in the famous "governance at the doorstep of the people" mantra. Despite the critical roles of MMDCEs, the historical political capitalism through which African politicians hap on political power to cultivate wealth raises stakes in the appointments of MMDCEs in Ghana (Ake, 1981). Varied interests coalesce to make the process of appointing MMDCEs challenging and scenes of interesting partisan politics. The result has been a blatant politicizing of the process to award party favourites in a travestying way to the Constitution of Ghana. Constitutionally, the appointment of MMDCEs, is the duty of the President subject to approval by the general assembly of the respective MMDAs [as will be seen later] based on competence and citizenship and nothing else. Partisanship seems to become the primary yardstick of ascending an MMDCE throne.

As a beacon of electoral democracy in Africa, Ghana held another successful general elections in 2016 that led to the New Patriotic Party (NPP) resume the reign of government after eight years in opposition, and had to fulfil the Constitutional mandate of appointing MMDCEs to form a government for the next four years. The appointment process created political "drama" that deserve academic attention to inform the literature on the politics of decentralization. But the focus of the paper is "politics in decentralization" as against "politics of decentralization". The 
former is essentially the politics that ensue a decentralization and embodied in the administration of a decentralized system. The latter refers to the politics involved in the design of a decentralized system. The appointment of MMDCEs is much of running a decentralized system for which reason the emphasis is on the politics in decentralization.

In this article, I examine the political dynamics that surrounded the appointment and confirmation of the 2017 MMDCEs vis-à-vis the constitutional proscription of the politicization of such appointments. The paper proceeds as follow: Section II takes the theoretical debates on presidential appointments; Section III borders on the issue of Ghana's decentralization supposedly an anti-political system; Section IV the process of appointing MMDCEs in the purview of the Constitution; Section V delves into the actors and the politics involved in the appointment process; Section VI looks at the political furore in the appointment process among the actors; Section VII examines the question of whether making MMDCE position elective will resolve the issue; and Section VIII concludes.

\section{POLITICS OF PRESIDENTIAL APPOINTMENTS: THE THEORETICAL DEBATES}

Since the late nineteenth century, there has been a debate among political scientists, political economists, public administration and management scholars on the degree of politicization and staffing of bureaucracies with political appointees. Some of the earliest scholars to engage with the politics-bureaucracy question include Woodrow Wilson, Max Weber and James Wilson, hence forth classical scholars (Sérgio et al, 2011). The engagement with this issues stems from the critical interrelationship between politics and public administration (Wilson, 1887).

In The Study of Administration, Wilson Woodrow argued that politics is the activity of the statesmen and bureaucracy is meant for technical people, who are unpartisan and are concerned with the implementation of the policies of a national government - irrespective of their party affiliation. Statesmen and bureaucrats, however, have a working relationship as he noted: "administration lies outside the proper sphere of politics. Administrative questions are not political questions. Although politics sets the tasks for administration, it should not be suffered to manipulate its offices". Presidential appointments of MMDCEs on partisan and other grounds as in Ghana, rather than technical competencies contrasts with Wilson's position on making bureaucrats truly public officials, and as staff of all governments - present and subsequent - which has effect on how local administrations are ran. Allern et al (2011) noted that the resilience and immunity of public offices to political manipulations is a function of the state institutional and meritocratic systems' capacity. In other words, in a context of weak state and meritocratic set ups, appointments are politicized. This explains, to some extent, the politicization of decentralization in contravention to the Constitution of Ghana.

Max Weber shared similar view with Woodrow that politics and bureaucracy be separated entirely from each other. He argued that bureaucracy should be "impersonal" and neutral system in order to make them absolutely necessary. The idea of impersonality as invoked by Weber to signify that bureaucracies should not be controlled or captured by so called big men in the political front. Nor, as neutrality may suggest, bureaucracies be used to serve political whims rather than the public good. De-personalizing bureaucracy untightens the grips and influence of party elites on local governance systems.

While Wilson Woodrow and Max Weber share a purist position on separation of politics and bureaucracy, James Q. Wilson (1975) had also recognized the need for a separation between the two but not a purist. His position was that politics should be distinct from bureaucracy. He contended that the two cannot be completely decoupled, though bureaucracy is supposed to 
assume a dominant position. However, bureaucracy can cede its proper position to politics under three conditions: when the administrative structure grows beyond public control; when power is placed in private rather than public hands; and when discretionary power of public agencies are irresponsive to the common good.

The second and third conditions - placement of power in private hands and irresponsive public authority- much denote the heavy politicization of MMDCEs in Ghana. Chief executives are perceived by the public as wielding power and setting the agenda for affairs in the districts. Even though elected assembly members in principle check and constrain the power of MMDCEs, they tend to be less capacitated, petty and more partisan which undermines this role. As Adamtey (2014) noted, attempts by assembly member to "check" an MMDCE make members a target for elimination in subsequent local assembly elections. And as a consequence MMDCEs become more powerful, gaining more private control over local bureaucracies - they hold the power and direct where the public is led. The ability of MMDCEs to effectively threaten some assembly members with loss of seats in elections resonates with Eaton et al. (2010: 14)'s point that while local election frees local governance from central government strings and enhance effectiveness, "Subnational elections can also have the opposite impact. National officials can use the perquisites of incumbency to support their favored candidates in subnational races, thus widening and deepening the networks that sustain governing and/or hegemonic parties".

The extent to which political parties can gain hegemony in controlling local governance structures depends on the type of electoral system prevailing. For example, in a first-past-thepost system which permits winner takes all, Sérgio et al, (2011) argued politicization of bureaucracies will be means of gaining control of public administration systems for distribution of political spoils. As will be seen later, MMDCE positions are perceived as reward for party loyalty and hard work and contribution towards electoral victory. This reward stream is expected to extend to grassroots party supporters in the districts who played one role or another for a party to come to power. In Ghana, the winner takes all system and its interaction with appointment of heads of local government areas is not far from this case. This depicts what Thies (2001) called "ministerial government", involving in toto assignment of party members into MMDCE portfolios. The effect is that bureaucratic performance is undermined, and in some cases competent responsiveness gives way to political responsiveness (Sérgio et al, 2011).

It has been argued that staffing bureaucracies political appointees leas to low performance. Lewis (2006; 2007) ascertained that political appointees perform systematically less than (non-partisan) appointees from civil service. This disproves the growing view in Ghana that a ruling party can only effectively execute its development agenda when bureaucratic appointees bear their party identity and signs up with the party's ideology and development agenda. Partisan appointments are less for effective execution of government programmes but more for rewarding party loyalists. It is for this reason that the Ghanaian Constitution provided the decentralization system in Ghana be apolitical and non-partisan. But is this really the case?

\section{GHANA'S DECENTRALIZATION: ANTI-POLITICS MACHINE?}

Unlike many other countries, Ghana's decentralization is apolitical at least on paper. However, reality has proven that the decentralization system in Ghana is far from being non-partisan, though the local governance space is perceived neutral. Ghana's local governance is nevertheless more political as if the legal frameworks establishing it had permitted its politicization. The two major legal frameworks that established the local governance systems are the 1992 Constitutions of Ghana and the Local Government Act 462 1993. These are 
complemented by, Ayee (2008) noted, standing orders, by-laws and legislative instruments, such as the District Assemblies Common Fund Act 455, 2003; and the Local Government Service Act 656, 2003. There are four levels of governance in Ghana: the central/national government; regional governance which are 10 in total (10 Regional Coordinating Councils, RCC); Metropolitan, Municipal and District Assemblies (MMDAs); and sub district structures: urban, zonal and town councils, and unit committees.

The districts ${ }^{3}$ in 2017 numbered 216 metropolitan, municipal and district assemblies (MMDAs). Out of this, six (6) are metropolitan assemblies, with minimum population of 250, 000; 49 are municipal assemblies, with minimum population of 95, 000; and 161 are district assemblies, with minimum population of 75, 000. The MMDAs and the sub-district structures combined represent the local governance system in Ghana - the building units of the decentralized system. MMDAs perform various functions in the areas of development planning, rating, administration, and budgeting. In total, MMDAs perform 86 functions (Ayee, 2008) executed by the decentralized agencies and departments such as the District Agricultural Development Unit, the District Health Directorate, the Works Department, District Education Unit, District Planning and Coordinating Unit etc. The objective of MMDAs as local government units is to deepen democratic governance and to promote local economic development (Republic of Ghana, 1992; 1993). To achieve these aims districts are mandated to create committees and sub-committees which are established along some functional lines. Districts have two main committees: the Executive and the Public Relations Committee and the Complaints Committee. These are supported by 5 mandatory sub-committees namely: Development Planning Sub-committee, Social Services Sub-committee, Works Sub-committee, Finance and Administration Sub-committee, and Justice and Security Sub-committee. However, districts are permitted under the 1992 Constitution and the Local Government Act 4621993 to create sub-committees where appropriate and necessary (ILGS and FES Ghana, 2010).

Districts are run by assemblies made up of representatives from the various electoral areas under the district. The 1992 Constitution and the Local Government Act 4621993 stipulate that 70 percent of the members that form the general assembly of each MMDA must be elected and 30 percent appointed by the President. These same legal frameworks require that, local governance be completely devoid of politics and meddling by political parties. Political parties are neither allowed to support or sponsor candidates for assembly membership during local government elections. Furthermore, candidates seeking elections into the various assemblies are prohibited from using any known political party's symbol ${ }^{4}$. The writers of these laws perhaps anticipated that depoliticizing the Ghanaian local governance would have positive impact on local and national development especially in ensuring the achievement of the two main aims of decentralized local governance: democratic governance and local economic development. In Ayee (2008)'s view, this will result from the ease of consensus-building around local development issues emanating from non-partisan local governance system. In other words, framers of the local governance laws might have thought that politicizing local governance will not auger well for effective local governance system in Ghana.

However, national partisan politics has trickled down to the local level with both sharing common features such as the vivid display of partisan politics during local assembly elections and the recent activities of political party youth vigilantism seeking political space to operate at the local level. The assembly members are more partisan than we can legally imagine by

\footnotetext{
3 District is an all-embracing term for metropolitan, municipal and district assemblies
}

${ }^{4}$ See the 1992 Constitution of Ghana and the Local Government Act 4621993 
contesting for assembly membership on implicit political party basis, and sometimes receive support from political parties during local assembly elections (see Adamtey, 2014). Even electorate at local level elections consider such elections partisan and vote candidate thought to belong to their party. Thus, partisanship has crept into the entire local governance structures ${ }^{5}$ from election of assembly and unit committee members to influencing the decisions they make and favor at the local level including their voting pattern during MMDCE endorsement ${ }^{6}$. However, the nature of politics at play in the local governance structures can be described as secret politics that is hard to notice.

Moreover, the politicized decentralized system is also exhibited in the creation of new districts. Despite the challenges new districts face in Ghana (Mensah et al., 2016), politicization has resulted in the constant creation and duplication of districts for political and partisan reasons such as electoral advantages. This is depicted in the creation of districts at the eve of elections and the siting of district capitals (Ayee, 2008) as well as the appointment of heads of those districts. Safely, the design of decentralization in Ghana is politicized just as its running - as will be seen latter.

Therefore, the aim of the relevant legal frameworks to create local governance machine that is anti-political and effective is less successful. Instead, local governance in Ghana has become political machines fueled by partisan politics in all respects. It remains unclear why the intent of the Constitution has proven difficult to achieve. But part of the explanation lies within the Constitution itself in the form of lack of internal consistency. While at one level the Constitution provided for non-partisan local assembly elections, it, at another point, called for the appointment of the head of the assembly and a third of the general assembly by the president. Though some assembly members are also appointed just like the MMDCE, appointment of a third of the assembly by the President does not receive such political recognition as the MMDCE because assembly membership positions are less valuable and more or less not influential. This is why Adamtey (2014) proposed that for local governance to be more effective assembly members need to be paid salaries. Beyond conventional partisan politics, MMDCEs appointments are surrounded by contentious politics marked by furor. While it is clear that Ghana's decentralization is far from being apolitical, what and where lies the politics in the appointment of MMDCEs?

\section{NOMINATION AND CONFIRMATION OF MMDCES IN GHANA}

An examination of the legal frameworks underpinning Ghana's decentralization reveals that there two stages in the appointment of MMDCEs. These are: 1] the nomination stage and 2] the confirmation stage. In this section I explore these stages and hint at (before elaboration in the next section) some of the politics involved in each of the stages of the appointment process.

\section{The Nomination Stage:}

Article 234(1) of the 1992 Constitution states "There shall be a District Chief Executive for every district who shall be appointed by the President..." Similarly Article 20(1) of the Local Government 1993 (Act 462) states: “...the District Chief Executive for each district shall be appointed by the President..." Thus the appointment stage, referred in this paper as nomination stage is deemed more appropriate because the President's appointment is subject to approval at the local assembly, is where the President (often taken as the president and his governing party) assess qualifies citizens of Ghana who have expressed interest in becoming

\footnotetext{
${ }^{5}$ See details at: https://www.ghanaweb.com/GhanaHomePage/politics/Minister-dissuades-assembly-membersfrom-partisan-politics-561991

${ }^{6}$ Further details at: http://www.peacefmonline.com/pages/politics/politics/201705/313772.php
} 
MMDCEs based on merit, and in according with the laws nominate qualified and competent citizens to the various MMDCE positions. But party allegiance, as shown above, has become an overarching, unconstitutional requirement at the nomination stage.

As a conventional practice, sitting presidents form committees usually of party members and executives, to assess MMDCE candidates for the President to take a final decision. A triplicate committee system was established to conduct the assessment of MMDCE candidates in the 2017 MMDCE race. These are the Constituency/District ${ }^{7}$, Regional and National Selection Committees. The National Selection Committee provided "policy" guidance on, for example, assessment criteria with which the Constituency, and then Regional Selection committees vetted candidates. List of qualified constituency level candidates are forwarded to the Regional Selection Committee for further scrutiny and onward transmission of shortlisted candidates to the National Selection Committee, which make final scrutiny and sieving and then makes final list of qualified candidates available to the President for a decision on who the MMDCE should be. The 2017 MMDCE National Selection Committee was chaired by the National Chairman of the ruling NPP. National chairman is in a good position to tell candidates that made significant contribution to the party's victory at the constituency level and the district concerned. This appointment stage of the process is usually characterized by less or no tension except lobbying, counter-lobbying, rallying by supporters, manipulation of candidates/nominees' lists and bribery $^{8}$. For instance, NPP youth in the Builsa North District violently rejected the nomination of David Afoko as DCE contending that “David Afoko's name was not among the final two aspirants that were taken to Accra [National Selection Committee is referred to] for the selection, and wondered who might have smuggled his name into the list and why he was selected over the two persons - Charles Abachisa and Alhassan Gariba"9. As argued by Professor Ransford Gyampo of the University of Ghana's Center for European Studies, the process of appointing MMDCEs lacks meritocracy. Party executives - constituency and regional - are alleged to take bribes from individuals vying for MMDCE positions ${ }^{10}$.

\section{The Endorsement Stage:}

Article 20(1) of Act 462 states that the nomination of MMDCEs by the President at the first stage is subject to "...the prior approval of not less than two-thirds majority of the members of the District Assembly present and voting at the meeting" that is intended at approving the nominee. Where a nominee fails to secure two-thirds of votes but gets more than 50 per cent in the first round of voting, he/she has the chance of a second round of voting. And where a nominee obtain less than two-thirds and then less than 50 percent, the nominee is replaced by another nominee for approval by the assembly subsequently. As we will see in the subsequent sections, this stage is the most tumultuous and tensed stage in the process of nominating an MMDCE. This stage unlike the nomination stage is characterized by tension partly because of information asymmetry between the public and the selection committee; people are not in the full know of what is going on the nomination stage and thus are uncertain of the prospects of

\footnotetext{
7 Ideally, the nomenclature would be District Selection Committee given the process is supposed to be apolitical. However, Constituency, a purely political, electoral area was popular in the media. This signals politics tramped especially since candidates are sometimes assessed based on their contribution to the party's electoral success in the constituency (ies) under the district. So I stick to Constituency in this paper.

8 See details at: https://www.ghanaweb.com/GhanaHomePage/diaspora/Some-government-officials-extortingprospective-MMDCEs-Prof-Martey-tells-Akufo-Addo-527588

${ }_{9}$ See details at: https://www.ghanaweb.com/GhanaHomePage/diaspora/NPP-youth-reject-David-Afoko-asBuilsa-North-DCE-532851

10 See details at: https://www.graphic.com.gh/news/politics/npp-supporters-protest-mmdces-vettingprocess.html
} 
the candidate they support. The endorsement stage is a revelation stage that bridges the information gap at various level of the party hierarchy leading to varied reactions to the nomination outcomes. For instance, the districts were largely peaceful until $28^{\text {th }}$ April when the President announced the first batch of 212 of the 216 MMDCE nominees in 2017. To be sure, the nomination and the endorsement stages are distinct but not separate; the nomination stage serve as input into what happen when nominees are announce for confirmation.

While the legal provisions do not explicitly call for appointing MMDCEs from only the ruling party, presidents - past and present - often hide under the pretext of loyalty to appoint solely party members into MMDCE positions. Though unconstitutional, loyalty to the president's party rather than meritocracy has become a key criterion to being appointed into an MMDCE post ${ }^{11}$. The Acting General Secretary of the ruling NPP, in 2017 declared succinctly: "Loyalty is key in this arrangement and it is one of the main criteria that will be used,"12 in assessing and appointing MMDCEs in 2017. In other words, partisanship is primary in the appointment process and qualified candidates of other political persuasions are automatically unqualified.

In effect, the political neutrality of the process is tainted thereby creating assembly/unit/electoral area elections implicitly contested and operated along party lines. This cascade to the districts' conduct of affairs along partisan trajectories (Adamtey, 2014). While Adamtey (2014) has depicted the relationships between MMDCEs and assembly members as "informal ties" such description hides the politics within the local governance.

The Chief Executive position in a district receives more attention of political actors relative to elected assembly members. Chiefs, opinion leaders, tribal and ethnic groups, political party youth groups, among others have shown great interest in who is nominated and approved to become the chief executive of their local government area. These interest groups often have preference for different candidates, and use different means to get their preferred candidate nominated and confirmed into the executive position. The commonest, though inappropriate because of the negative consequences, is violent protests and demonstrations.

Violent actions abound at the grassroots due to disagreements about candidates confirmed for MMDCE position. While this disagreements might not be bad per se, their manifestations, expressions and management cannot be described as appropriate. Lobbying and counter lobbying is often employed at the nomination stage, while picketing, street rampages and demonstrations characterizes the endorsement stage and thereafter. The use of violent protests is common among party activists especially youth, and has by and large become perennial: every new government in Ghana's Fourth Republic, has to contend with them. For example, the Prof. Mills administration (2008-2012) witnessed such violent demonstrations. This seemed to have worked to some extent for complain about an MMDCE's misdemeanor or demonstration staged by party youth groups against an MMDCE almost always amounted to dismissal or change of such MMDCE ${ }^{13}$. Because of these, citizens in general, political leaders and people in government (particularly the Local Government Minister) are often worried about how locals' will react whenever MMDCE nominees are announced. For example when the first batch of the 2017 MMDCE nominees were announced, and recorded no immediate resistance by local folk, the local Government Minister was elated and proclaimed that the MMDCE appointees were "well received" while the Chairman of the National Selection

\footnotetext{
11 See further details at: http://www.myjoyonline.com/politics/2017/february-13th/appoint-mmdces-based-onmeritocracy-gyampo-to-govt.php

12 Find details at: http://starrfmonline.com/2017/02/14/mmdce-appointments-loyalty-key-npp/

13 See details at: http://www.ghananewsagency.org/features/the-avalanche-of-demands-for-resignation-21663
} 
Committee, the National Chairman of the NPP, praised the Committees for doing a very good job i.e. selecting MMDCEs the people accepted. ${ }^{14}$. This indicates that government (officials) are often concerned about and anticipate such reactions to appointments yet such actions persists.

\section{THE POLITICS OF MMDCES APPOINTMENT IN GHANA}

In this section I examine the actors and the petty politics involved in the appointment of MMDCEs.

\section{Partisanship in MMDCEs [Nomination and] Endorsement}

Partisan politics has translated into a difficult process of confirming MMDCE nominees. As indicated earlier, the law requires that, any MMDCE appointed by the president must secure the approval of the respective general assembly to become fully recognized as such. This endorsement stage is the biggest challenge in the sense being highly partisan stage of the process of appointing an MMDCE into office. Partisanship has translated into district assemblies in Ghana being divided into two main caucuses along the lines of the two main political parties in Ghana: National Democratic Congress (NDC) and New Patriotic Party (NPP), which have alternated power since the return to constitutional democracy in1992. Almost every single assemble in almost all the districts in Ghana are divided along NDC-NPP sects. These internal partisan lines in the various assemblies are by-products of the politics that characterize local assembly elections, and are exhibited when it is time for the General Assembly to (un)confirm an MMDCE nominated by the President.

The partisan cracks within district assemblies have significant implications on the process of confirming or rejecting a nominee. The alternation of power between NDC and NPP since 1992 has created and sustained historical divisions. The dominance of these two political parties has led to assembly members aligning with either of these big parties. This is because non-aligned assembly members risk not coming back to the assembly in the next sessions. The reason being that political parties clandestinely fund their candidates during local elections, and confirmed MMDCEs sometimes do calculated sponsorship of candidates to make sure "stubborn" assembly members lose their seats (see Adamtey, 2014).

These political divisions in the various assemblies could mean that sheer rejection of an MMDCE nominee can happen due to extreme partisanship rather than incompetence or incapability of the candidate concerned. This partisanship effect has played out in a cyclical manner in the nomination and (un)confirmation of MMDCEs when any of the two main political parties wins elections. This means that the extent to which MMDCE nominees of a ruling party gets approval from the assembly is dependent on the proportion of assembly members that are on the ruling party's side. In cases where the ruling party has comparatively less (less than the two-third of members present to vote) members on its side in a particular district assembly, it will be a staggering hurdle for a nominee to get approval at the general assembly. With this logic, political parties make efforts to ensure their party loyalists win assembly elections so as to gain control of local governance affairs and to make approval of MMDCEs smooth should the party win elections. This suggests that MMDCE nominees who find themselves appointed to MMDAs where the ruling party is in the "minority" would have to find ways to secure the required votes to go through the approval process successfully, otherwise he/she is replaced, an outcome every MMDCE nominee would abhor.

${ }^{14}$ Further details at: https://www.graphic.com.gh/news/politics/mmdce-appointments-well-received-hajiaalima-mahama.html 
It is common knowledge in Ghana that there is some vote trading and that some MMDCEs buy their approval and confirmation into office. MMDCE nominees are perceived to offer financial considerations in return for the votes of assembly members ${ }^{15}$. One way to test the veracity of vote trading during MMDCE nominees' approval is the number of rounds of voting before an MMDCE is finally approved. A good number of MMDCE nominees have to go through second round of voting and some even third round before they finally approved or rejected by the assembly concerned. This is not to say those who secure approval during first round of voting do not buy votes or that they do. Nor does it suggests all those who secure approval after first round of voting trade votes. But it is also possible that MMDCEs that secure approval during second and third rounds of voting have bought their way through. This is because, what would have changed the minds of assembly members within the short period after rejecting a nominee in the first round?

The case of West Mamprusi District (Walewale) will bring clarity: the President's nominee was voted against in the first round of voting. In the second and third rounds of the confirmation processes, he was rejected. This indicates that the reasons for which assembly members would reject a nominees are unlikely to easily change within few weeks if not days to the subsequent rounds of voting, if the reasons are not mere partisanship. This notwithstanding, some MMDCE nominee are able to secure confirmation after the first round rejection. But these are often perceived as bought confirmations and money usually exchange hands. The prevalence of first round rejections of MMDCE nominees during confirmation are often interpreted as indirect demand for rewards and benefits before confirming such a nominee in second or third rounds of voting. However, the possibility of the opposing party having majority of the assembly cannot be ruled out entirely. The notion of vote trading led to violent protest against the confirmation of the Savelugu Municipal Chief Executive, whose confirmation was interpreted to involve bribing of assembly members for which reason party youth staged series of protest against her nomination and confirmation ${ }^{16}$.

To be sure, rejection of some MMDCE nominees and the violent demonstrations against their nominations could be orchestrations of political opponents. Because inside-party opponents who have special interests in a district and unsuccessful candidates at the nomination stage do not easily give up thereafter; they launch themselves onto the endorsement stage and still "fight" secretly. The informal ties with youth groups, tribal and ethnic fraternities, religious and traditional leaders, are potential ways to capitalize on by opponents to MMDCE nominee (Adamtey, 2014) to scheme the disapproval of some MMDCEs. These ties could be used to try to undermine a nominee's popularity and endorsement at the assembly. Some hire these youth groups to mar the confirmation process through staging of unwarranted, violent protests. As a case, the Bunkpurugu/Yunyoo Chief Executive nominee's appointment and confirmation was alleged to have been sabotaged by big powers in the NPP party using his power simply because the nominee was not his preferred candidate. Party youth group in the District alleged that the MP for the area who doubled as Deputy Northern Regional Minister, and the Northern Regional Minister were sabotaging the confirmation of the Chief Executive nominee. On the other hand, the Member of Parliament (MP) for the area, and the Northern Regional Minister were blaming the Northern Regional Chairman of the NPP for instigating the instability and violence in the

\footnotetext{
15 See details at: https://www.graphic.com.gh/news/politics/npp-supporters-protest-mmdces-vettingprocess.html

16 Details here: https://www.ghanaweb.com/GhanaHomePage/NewsArchive/Violent-demonstrations-preventSavelugu-MCE-from-reporting-for-official-duties-547657
} 
area and the refusal of the assembly members to confirm the DCE nominee ${ }^{17}$. Casting aside the veracity of this and who really forestalled and frustrated the nominee's approval, it points to the politics and power at play in indorsing MMDCEs.

Moreover, the failure of some candidates' bid to get nominated by the President is blamed on manipulation by some powerful individuals within the party creating the impression that MMDCE candidates' lists are sometimes "edited" before presentation to the President. In Agona West District, the President's nomination of Madam Justina Marigold Assan, over Mr. Evans Onomah Coleman, as the DCE was blamed on the MP for the area Mrs. Cynthia Morrison for manipulations and lobbying at the presidency to make futile Mr. Evans Onomah Coleman's (the Chairman of the NPP in the area) bid ${ }^{18}$. One would expect that a party chairman and its MP for the same constituency would have cordiality in the interest of the party. But this case suggestion that private scores and squabbles carried to the nomination and endorsement of MMDCE. If an MMDCE nominee or candidate is not in the good books of some big party men, they may suffer machinations in their bid.

\section{Traditional Authorities and MMDCEs Nomination and Endorsement}

Traditional authorities and chieftaincy institutions also take part in the political process of appointing MMDCEs. Though those institutions are getting less powerful than before, chiefs still have and control following in their jurisdictions. Powerful chiefs' blessing is sometimes needed to secure a successful bid to become a nominee and subsequently get confirmed. In some cases the disapproval of the chief will lead to a candidate's name not enlisted and submitted to the President. By extension, chiefs' approval is equally required to successfully complete a tenure as an MMDCE. This is because "chiefs are (hold) political and social power centers in their areas of jurisdiction" (Ministry of Chieftaincy and Traditional Affairs, 2014), have very strong links and respected in mainstream politics by politicians in Ghana (Knierzinger, 2011) including politicians who matter in the process of appointing MMDCE. Some traditional leaders are respected and have links with the President with whom they have direct communication. It is difficult to extricate the traditional chieftaincy institution from mainstream politics. Some the leadership in the traditional institutions are retired politicians and public servants with sound understanding and long-standing network in mainstream politics before assuming traditional titles.

Though the involvement of the traditional authorities in the MMDCE appointment processes is assumed and contrary to the 1992 Constitution which prohibits chiefs from active, public politics, they still remain influential whenever they decide to dip into in who becomes an MMDCE. Sometimes a chief's disapproval of the President's nominee will not make the nominee reach the endorsement stage before his replacement by another. When the Regent of Tolon, Major (retired) Sulemana Abubakari, rejected Hajia Amama Sayibu as MMDCE her bid died with the Chief's disapproval ${ }^{19}$. The chief's rejection became a basis for and emboldened already disgruntled youth to undertake violent demonstrations against the President's choice, eventually resulting in revocation of her nomination.

\footnotetext{
${ }^{17}$ Further details at: http://citifmonline.com/2017/06/30/tension-mounts-in-bunkprugu-over-dce-nomineesconfirmation/

18 See details at: https://www.ghanaweb.com/GhanaHomePage/diaspora/Agona-West-MP-had-no-hand-inappointment-of-MCE-Organiser-533372

${ }^{19}$ See details at: http://dailyguideafrica.com/tolon-regent-reject-dce-nominee/
} 


\section{Party Youth Groups and MMDCEs Nomination and Confirmation}

Another informal confirmation stage MMDCE nominees need to pass and sometimes contend with is political party youth groups' blessing and consent. Ayee (2008) underscored that party youth groups have had interest in various aspects of the local governance system in Ghana including the creation of new districts and the siting of district capital. This is in tandem with the significant role party youth groups (popularly known as foot soldiers/vigilantes) play in Ghana's politics (Bob-Milliar, 2012). Indeed, one such assumed roles they play concern the process of appointing MMDCEs. Party foot-soldiers especially those based in the districts have very high stakes in who becomes the MMDCE. This is because foot-soldiers are part of the informal ties and political capital of politically exposed persons (Adamtey, 2014). These groups literarily fight and are ready to die for their party to come to power by serving as political apparatchiks (Gyampo, 2011). These sacrificial service offered by vigilante groups are by and large free to the party during opposition times. But on one promise: that when the party comes to power, meagre jobs and contracts such as cleaning of streets and taking care of public toilets will be awarded to them to eke a living, and as reward for their service to the party's electoral success. Because of these sacrifices and the promises made to them by the political parties during electioneering period, party youth take high interest in who becomes the MMDCE.

To ensure that they get the menial jobs and contracts promised them, vigilantes do everything possible to ensure that a tough (a candidate who could deny them their opportunities) person does not assume the role of MMDCE; anything short of this tantamount they losing the opportunity to get their share of the political spoils they have been yearning and waiting for. To get a "good" person to occupy the office of MMDCE, party vigilantes adopt various means to make sure they get their preferred candidate into the MMDCE post. One such means is the use of violent protests. Matching and protesting peacefully is seen as a weak approach and would not produce the needed attention from the people who really matter. Not only that peaceful demonstration is overlooked, irate youth defy formal party grievance procedures perhaps because they grind slowly, though such aggrieved youth are often adviced to follow laid down procedure in addressing their concerns ${ }^{20}$. Therefore, violent demonstration is often preferred as opposed to the slow grinding party complaints and grievance procedures. Party youth group in the Walewale District in the Northern Region resorted to violent protest against the district chief executive nominee in the District. They destroyed party offices and properties to show their displeasure and disapproval of the nominee ${ }^{21}$. Party youth did not forget to vandalize the Zebila District Assembly and NPP party offices to register their dislike toward the chief executive nominee just as in the Builsa District youth did not spare destruction of NPP offices over a DCE choice they did not favor. In the last case, the youth groups vandalized decentralized departments such as the Non-Formal Education Unit, the National Disaster Management Organization, and National Youth Employment Agency etc. and seized office equipment such as computers and office furniture 22 .

Economic factors are the fundamental basis upon which party vigilantes are trying to ensure a tough person does not assume the role of an MMDCE. As Ake (1981) posits: economic needs are the primary needs of man the same way economic activity is man's topmost priority. This author argues that man eats to live. But before he can eat he must work. Party vigilantes are thus fighting to get rid of obstacles - potential or real - that can stop them from getting to work

\footnotetext{
20 See details at: http://citifmonline.com/2017/06/24/bugri-naabu-appeals-to-rampaging-npp-youth-inwalewale/

${ }^{21}$ See further details at: http://citifmonline.com/2017/06/25/police-hunt-for-rampaging-npp-youth-inwalawale/

${ }^{22}$ Details at: https://www.newsghana.com.gh/npp-youth-in-zebilla-protest-against-dce-nominee/
} 
and thus eating (Armah-Attoh, 2017). This is common perception among Ghanaians. The Afrobarometer survey revealed that 6 out of every 10 Ghanaian believe party vigilante groups engage in party politics for material gains. Thus, political party executives including potential MMDCEs that are perceived as threats to party youth's anticipated gains are violently rejected. The result is sometimes violent confrontations between party vigilantes and those executives that appear as obstacles on their way to reaping the benefits that they toiled for, as in the case of party youth groups and party executive brawl over the DCE nominee in the Bunkpurugu/Yunyoo District.

A related point to Ake's primacy of economic needs as the basis for youth politically violent reactions is Honwana (2016)'s idea of "waithood". Honwana thinks that not only are economic opportunities eluding the African youth, but that they have to wait indefinitely to the extent that they are trapped in between adolescence and adulthood - where they are neither the former nor the latter. This is because they cannot leave the lifestyle socially expected of either adolescence or adulthood. He concluded: "Uncertain, unable to find secure jobs, and caught in the liminal state of 'waithood', young people are angry and are on the march across the world" - that is they rebel. They are thus left with the choice of either to confront governments or keep waiting. Besides, such a situation makes party youth vulnerable to recruitment for inappropriate purposes such perhaps scheming a demonstration against fellow contestants in an MMDCE race in a district. To be sure, the increasing role of these party youth in Ghana's politics could be a product of democracy's open space for broader participation which party youth are taking advantage of mis-act.

\section{Party Executives and MMDCEs Nomination and Endorsement}

Besides political party vigilante groups, party executives, especially the district/constituency level party executives, also have their interest which they pursue, and this contributes to the political bickering surrounding the appointment MMDCEs. For instance, recently the BoleBamboi District Chief Executive and the NPP Constituency Chairman of the area were engaged in a brawl over the National School Feeding programme in the District. Similar incident took place in the Ejisu-Juaben Municipality where the Women Organizers of the NPP in the Constituency were fighting it out with the MCE over the School Feeding Programme. The common denominator in these contentions sharing of benefits and opportunities emanating from the Programme where one party accuses the other of sharing the opportunities of jobs with other party members. The NPP youth in the area picketed at the Municipal Assembly premises to draw attention of the MCE to their displeasure with her giving jobs under the School Feeding programme to people who are not loyalists of the NPP after they (the youth) have worked hard to bring the party to government ${ }^{23}$. At the regional level, the Bunkpurugu/Yunyoo case cited above demonstrates that party executives above the constituency level are involved in the controversial politics of who becomes an MMDCE in a particular district.

A survey of media accounts of the political controversies reveal key aspects around which political/party actors have furor over during the nomination and appointment of MMDCEs. The following section examines these issues.

\section{ELEMENTS OF POLITICAL FURORE OVER MMDCES' APPOINTMENTS}

The nomination and confirmation of MMDCEs to the various MMDAs involves contentious aspects namely: 1] Furore over nominee's Identity (whether he is an indigene); 2] Furore over

${ }^{23}$ See details at: $\underline{\text { http://mynewsgh.com/npp-chairman-dce-fight-over-school-feeding/ }}$ 
qualification of nominee and 3] Furore over nominee's party commitment. I take these elements in turn.

\section{Furore over nominee's identity (indigene and tribe)}

The appointment of MMDCEs often give rise to tension and renewed tribal/ethnocentric feeling among the tribal groups and communities that fall under a particular district's jurisdiction. One ethnic group in a district usually claims to be the supposed and qualified group to rule the others. Where a nominee happens to come from small tribe instead of the predominant tribe that often consider themselves as the ruling class, tension emerges and calls made for revocation and replacement of the nominee. The 1992 Constitution frowns on discrimination based on creed, religion, gender or tribe in the appointment of public officials by the President. But reality has shown that some major ethnic groups sometimes kick against nomination of MMDCEs on tribal and ethnic grounds in the districts sometimes in violent and threatening manner. Closely associated with the tribal/ethnic sentiments regarding appointments of MMDCEs is whether or not the nominee is an indigene of the district.

Several examples illustrate this point. Youth groups rejected the nomination of the Savelugu/Nantong Municipal chief executive, on grounds that she was not an indigene of the area. They argued that the MCE position cannot be occupied by an alien i.e. a non-Dagomba. However, the nominee rebutted the claims saying she was an indigene - born and bred by her parents who were both indigenous Dagombas of the area ${ }^{24}$. Similarly, the Tema Mantse (traditional chief of Tema) demanded that the nominee to the Tema Metropolitan Chief Executive position must be an indigene of the area just as the groups in Abetifi in the Kwawu East District protested against the appointment of DCE who was considered not a native of Abetifi. They protested and argued: "The Concerned Youth of Abetifi also wishes to appeal to the president to nominate Hon. William Owusu as the DCE for Kwahu East District since Abetifi has never been considered for the position ever since the Kwahu East District Assembly was established, regardless of the fact that Abetifi serves as the district capital. We firmly believe this is not fair to the people of Abetifi and its surrounding villages". Similarly, the people of Prampram resisted the appointee to the Ningo/Prampram District arguing that at least the DCE must come from Prampram since the MP, Hon. Sam George, hails from Ningo. ${ }^{25} 26$ This strikes accord with Ayee (2008) point that siting of district capitals is a controversy in Ghana's decentralization process. Embedded in these contentious issues of identity and the MMDCE position are issues of justice and fairness; demand for MMDCE not to always come from one tribe or a particular community - the need for power rotation. One thing worth noting is that the 1992 Constitution is silent on whether or not an MMDCE must be an indigene of the area or a resident though this is implied in the non-discrimination clause in the Constitution.

Why would people care about the tribe of the MMDCE when any qualified, non-in-their-tribe candidates might have done perhaps better? Part of the explanation can be gleaned from common discourse regarding high profile people like popular politicians in Ghana, in many other African country and perhaps generally as human nature to almost always want to be associated with positive things. People simply feel good and takes pride in knowing someone with a high profile or public figure. Similarly, it is not uncommon to hear people say so and so

\footnotetext{
${ }^{24}$ See details at: https://www.ghanaweb.com/GhanaHomePage/diaspora/Group-kicks-against-appointment-ofHajia-Seidu-as-MCE-533624

${ }^{25}$ Find details at: https://www.ghanaweb.com/GhanaHomePage/diaspora/Ningo-youth-reject-DCE-nominee$\underline{534976}$

${ }^{26}$ See story at: https://www.ghanaweb.com/GhanaHomePage/diaspora/Tema-MCE-must-be-an-indigene-TemaMantse-531505
} 
occupying that position is of my tribe. This associational glory of people taking pride in seeing people they know or acquainted with occupy certain position or attain a certain profile is one of the motivational factors behind the tribal sentiments that surround MMDCEs appointment in Ghana.

\section{Furore over qualification of nominee}

Partly because the legal frameworks underpinning the local governance system do not spell, beyond citizenship, other qualities a nominee to an MMDCE position must have, there is a vacuum for political actors to speculate. Political groups then come up with criteria, apart from being a Ghanaian, they think MMDCE must fit. Looking for grounds to stand on, political actors resort to qualifications, academic or otherwise, to discredit nominees. The qualification grounds are often coupled with violent protests and agitations for annulment of nominee's nomination. For example, in the Ahafo Ano District, party youth protested the nomination of Joseph Agyemang Dapaah as District Chief Executive contending that they were "not happy at all about Chairman Joseph Agyeman Dapaah as nominee for the DCE position. Nana AkufoAddo [the President] has disappointed us. We want someone who can read and write well". ${ }^{27}$ Suppose the claims of the protestors in the Ahafo Ano District are right that the nominee could not read nor write, it shows that partisanship overrides education and technical skills in the assessment process.

Thus, a nominee's contribution to the party's success far more compensates for and surpasses those who might be more qualified in terms of formal education and technical competence. This suggests that the absence of formal, objective selection criteria makes room for arbitrariness, and hence engender political and partisan abuse of the assessment and selection process.

\section{Furore over nominee's loyalty to the party}

A nominee's loyalty and commitment to the ruling party is considered weighty if an individual wants to vie for MMDCE position. Ruling political parties and their supporters seem to use MMDCE positions for awarding loyal, dedicated and diligent party members. Consequently loyalty has become a criterion for assessing who is and who in not qualified to be appointed to the position of MMCE. Also contribution to the party's victory and progress be it historical contribution which could in the form of one's parents and grandparents contribution and role in the party or one's personal in kind donation and personal sacrifice for the party in his life and/or during a particular election, which is often the election the party has won and forming government. How much a member and/or his family has suffered for a party is observed, monitored and measured during campaigning and electioneering periods, and the information stored for usage in assessing candidates for MMDCE positions should the party win an elections and the individual concerned show up in the contest.

The source of tension regarding commitment to party as yard stick for assessing MMDCE candidates lie in the subjective nature of measuring party loyalty and faithfulness. There is the inherent chance of one group considering a particular nominee as committed party member and the same person will be regarded as someone who has not made enough contribution to the party to deserve as MMDCE role. For instance, in the Builsa North District, NPP youth were against the nomination of David Afoko claiming that the nominee "David Afoko, though the Constituency Chairman, did not commit himself fully to the 2016 campaign". Similarly, NPP

${ }^{27}$ See further details at: https://www.ghanaweb.com/GhanaHomePage/diaspora/Tension-brews-at-Ahafo-Anoover-wrong-choice-of-DCE-533127 
youth in the Bawku West District were also against the nomination of "Madam Victoria Ayamga, whom they said did not commit herself to the campaign [i.e. the 2016 elections the party won and was setting up a government] and was rather supporting the National Democratic Congress". ${ }^{28}$

\section{WILL ELECTION OF MMDCES RESOLVE THE FURORE?}

Amidst the growing contentious politics in MMDCEs appointment, some are of the view that MMDCEs positions should be made elective. The increasing furore over the appointment of MMDCEs and politicization of MMDAs contrary to the laws are often cited as the justification. They argue that making MMDCEs elective is the surest way to finding a permanent solution to the perennial furore over Presidential appointments of MMDCEs.

I would, in section, limit the discussion to this common object i.e. to what extent electing MMDCE can resolve the furore and the implications of MMDCE elections on the functioning of local assemblies, though this second consideration is less prominent, it is important and should be the primary object instead of the former. The reason is that the basic essence of decentralization is better governance.

The making of MMDCEs elective was a campaign promise of the now ruling NPP party. This was re-echoed following the violence and agitations that greeted the release of the 2017 MMDCE appointees, the Minister for Local Government and Rural Development proclaimed: "the president, henceforth, will have no hand in their [MMDCEs] appointments; the power will be reserved to the people"29. Opening the ballot to all voters in a district to have a choice in who leads the district will engender participation, transparency, fairness and public trust in the process of selecting MMDCEs, and more qualifies candidates will have the opportunity to take part in the race. This could potentially reduce the brawl over the process but elections opens the flood gates for many actors to come into the process including other political parties, if it will be multi-party.

This point is more valid when examined in the purview of whether MMDCE elections will be multi-party contest. Suppose this will be the case, there will be intense campaign and heated contest. As local elections have different schedule than general elections, opposition parties will turn to such elections after general elections in the quest to have a voice in government. The desperation to at least have power at the local level could contribute to a more or less bitter contest and perhaps more contentious elections. This furore might even be a protracted one. Consider a situation where opposition wins majority of MMDCE seats and controls the local government system in Ghana with another party in power at central government. In this case the possibility of national government efforts being thwarted deliberately for political reasons will be high. Also, in this scenario, there is the danger of over dichotomy of local and central governments with negative consequences on national development. Thus, the contentious politics in the decentralized system will rather increase and protract rather than die down. Of course, there is the chance of incumbent party using incumbent advantages to support and sponsor their candidates and continue to maintain hegemony at the local level. As Eaton et al. (2010: 14) posited: "National officials can use the perquisites of incumbency to support their favoured candidates in subnational races, thus widening and deepening the networks that sustain governing and/or hegemonic parties". The case of Cambodia Prime

\footnotetext{
28 See details at: https://www.ghanaweb.com/GhanaHomePage/diaspora/NPP-youth-reject-David-Afoko-asBuilsa-North-DCE-532851

${ }^{29}$ For further details see: https://www.ghanaweb.com/GhanaHomePage/diaspora/President-will-no-longername-MMDCEs-Alima-Mahama-532481
} 
Minister Hun Sen and his ruling Cambodia People's Party (CPP) gaining hegemony after subnational governance in the late 1990s illustrate this point. Incumbent parties in Ghana are already exhibiting such tendencies in their campaign strategies of starving opposition parties organizational and financial resource wise (Brierley and Kramon, 2015) and in local assembly elections where scheming to remove assembly members is feared (Adamtey, 2014).

Nevertheless, "Regularly electing subnational officials (and eliminating the prerogative of the national government to appoint them) opens up the possibility that national and subnational offices will be won by candidates representing different political parties (or different political groupings in countries where parties are insignificant). In these situations, subnational officials may be able to use their separate democratic legitimacy to push for greater resources and responsibilities from below" (Eaton et al., 2010: 14). Local authorities might function better by delivering on their mandate when resources are acquired and used judiciously. The possibility of more responsive and accountable districts emerging is high. Elections time will be times for elected MMDCEs to account for their tenure base on which it is renewed or not.

This goes without analysing the possibility of an opposition party candidate winning a seats in the MMDAs. In such a scenario, we cannot over rule the chances that such MMDCEs will be victimized, sabotaged or frustrated in their efforts to carry out their mandates. We envisage discriminatory decentralization system emerging where some districts are starved of financial and other resources because they voted a candidate other than that of the ruling party's. Districts that are led by MMDCEs purported to be of the ruling party on the other hand would more likely be favoured in many ways including resources allocation. The aim of such tactics would be discredit MMDCEs not belonging to the ruling party. However, they would invest massively during campaign times to win over those districts, thus establishing hegemony. The existing tendencies lend credence to possibility of this happening. As Brierley and Kramon (2015: 2) noted: "access to state resources give incumbent parties a relative financial advantage over opponents. First, the incumbent is able to manipulate state resources for its electoral advantage before elections. Second, during the campaign the incumbent can use extra campaign funds to target voters across a large number of regions of a country. More specifically, it enables the incumbent to campaign in areas where they are not already electorally dominant". These ploys are not far from being employed in election of MMDCEs.

Making MMDCEs elective can go either way to make or mar the existing political furore over the appointment process. The emphasis should not be how to use the election of MMDCEs to resolve the contention but to strengthen the local governance system to make more effective for achieving the essence of decentralization.

\section{CONCLUSION}

The appointment of MMDCEs is highly politicized and partisan in a way that undermines the legal frameworks that institutionalized the local governance system in Ghana. This has further undermined the effective functioning of MMDAs and the achievement of the good governance and local economic development objectives (Ayee, 2008; Adamtey, 2014) envisaged by the framers of local governance laws in Ghana. MMDAs are more of political machines rather than anti-politics machines contrary to the Constitution and other related regal provisions. The extreme partisanship and politicization has created fertile grounds for political party youth groups and other social groupings to stage violent, destructive protests. The extent to which making MMDCE positions elective would somewhat reduce the tension and chaos that accompany MMDCE appointments and confirmation depends on the design and management of the election process which in turn would affect the functioning of MMDAs. This is because merely making MMDCE positions elective would simply be another electoral layer at the local 
level, bringing more political actors including parties, if the process is multi-party, into the process. Therefore, there is the possibility that making MMDECs elective could swing in either direction - i.e. make the process more politically contentious or reduce the political furore. If appointment of MMDCEs from a single ruling party without the involvement of other political parties, can prove this contentious, it is hard to conclude that making the process elective by bringing more candidates from different political leaning to the process will engender less contentions. But making the positions elective will most likely enhance the effectiveness of the local governance system, assuming no incumbent party hegemony.

The elements of furore in the presidential appointment of MMDCEs are more likely to get complicated rather simplified when elections are instituted. Take for example tribal and ethnic belonging; more ethnically diverse candidates are likely to emerge in the process given the socially diverse nature of districts. Not only this, political diversity will increase generating fierce electoral contests for which there is the likely of transforming intra-party furore into inter-party political/electoral violence.

\section{References:}

Allern, E. H., Bischoff, C. and Kristinsson, G. H. (2011). Political Control or Bureaucratic Autonomy? A Comparison of Public Appointments in Denmark, Iceland and Norway. Paper prepared for presentation at the 6th ECPR General Conference, Reykjavik.

Ake, C. (1981). A Political Economy of Africa. Nigeria: Longman Nigeria Limited and USA: Longman Inc.

Adamtey, R. (2014). Deepening Decentralisation through Non-Partisan District Assembly System in Ghana. Journal of Science and Technology, 34(1): 75-84

Amah-Attoh, D. (2017). Political Party Vigilantism: A growing fox worth killing before it mutates into a monster. Ghana Center for Democratic Development (CDD-Ghana), Elections policy brief, No. 4.

Ayee, J. R. A. (2008). The Political Economy of the Creation of Districts in Ghana. Journal of Asian and African Studies 48(5): $623-645$

Ankamah, A. S. (2012). The Politics of Fiscal Decentralization in Ghana: An Overview of the Fundamentals. Public Administration Research, 1(1): 33-41

Bob-Milliar, G. M. (2012). Political Party Activism in Ghana: Factors Influencing the Decision of the Politically Active to Join a Political Party. Democratization 19(4): 668-689

Brierley, S. and Kramon, E. (2015). Political Party Campaign Strategies and Incumbent Advantages in African Election. Working Paper Version 1.4, WGAPE.

Eaton, K., Kaiser, K. and Smoke, P. (2010). The Political Economy of Decentralization Reforms Implications for Aid Effectiveness

Faguet, J. P. (2011). Decentralization and Governance

Gyampo. R. E (2011). Political Apparatchiks and Governance in Ghana. Afro Asian Journal of Social Sciences 2(2.1): 2229-5313

Honwana, A. (2015). Enough! Will youth protests drive social change in Africa? African Arguments. Available at: http://africanarguments.org/2015/12/07/enough-will-youth-protests-drive-social-change-in-africa/ Accessed on: $28 / 08 / 2017$

Institute of Local Government Studies (ILGS) and Friedrich-Ebert-Stiftung (FES) Ghana, (2010). A Guide to District Assemblies in Ghana.

Kauzya, J. M. (2007). Political Decentralization in Africa: Experiences of Uganda, Rwanda, and South Africa

Krause, G.A., Lewis, D.E. and Douglas, J.W., (2006). Political appointments, civil service systems, and bureaucratic competence: Organizational balancing and executive branch revenue forecasts in the American states. American Journal of Political Science, 50(3): 770-787.

Knierzinger, J. (2011). Chieftaincy and Development in Ghana: From Political Intermediaries to Neotraditional Development Brokers. Gottenburg Univerty: Department of Anthropology and African Studies, Working Papers Nr. 124 
Lewis, D.E. (2007). Testing Pendleton's Premise: Do Political Appointees Make Worse Bureaucrats?. The Journal of Politics, 69(4): 1073-1088.

Litvack, J., Ahmad, J., Bird, R. (1998) Rethinking Decentralization in Developing Countries. Sector Studies Series. World Bank: Washington D.C.

Mohammed, A. K. (2015). The politics of municipal fragmentation in Ghana. Commonwealth Journal of Local Governance Issue 16(17): 168-189

Ministry of Chieftaincy and Traditional Affairs (2014). The Chieftaincy Institution in Ghana: A Model for Africa. Accra: Ghana

Ndegwa, S. N. and Levy, B. (2003). The Politics of Decentralization in Africa a Comparative Analysis

Sérgio, P, Freitas, A, and Hoepers, B. (2011), Political Appointments and Coalition Management in Brazil, 20072010. Journal of Politics in Latin America, 3(2): 141-172.

Treisman, D. (2000). Decentralization and the Quality of Government

Wilson, J. Q. (1975). The Rise of the Bureaucratic State. The Public Interest, 41: 77-103

Wilson, W. (1887). The Study of Administration. Political Science Quarterly, 2( 2): 197-222

UNDP (1999). Decentralization: A Sampling of Definitions. Working Paper of the Joint UNDP-Government of Germany Evaluation of the UNDP Role in Decentralization and Local Governance, October 1999. 